\title{
Non-native English lecturers' motivational practices in a tertiary educational environment
}

\author{
Sahril Nur ${ }^{*}$, Tri Indri Hardini' ${ }^{2}$, Andi Anto Patak ${ }^{3}$ \\ ${ }^{1,3}$ English Department, Faculty of Languages and Literature, Universitas Negeri Makassar, Makassar, South \\ Sulawesi, Indonesia \\ ${ }^{2}$ Faculty of Language Education and Literature, Universitas Pendidikan Indonesia, Bandung, West Java, \\ Indonesia
}

\begin{tabular}{|c|c|}
\hline $\begin{array}{l}\text { ABSTRACT } \\
\text { To fill in the gap on how tertiary educational envir } \\
\text { Indonesia use all motivational activities, this qualitat } \\
\text { about motivational strategies in the classroom, how th } \\
\text { EFL students think about their lecturers' motivational } \\
\text { embedded design in which participants from a single } \\
\text { clusters. Interviews with five non-native English } 1 \\
\text { students, observation, and field notes were utilised. Tl } \\
\text { types of motivation: natural and nurtured, with nurtu } \\
\text { The instructor element is central to motivation, accor } \\
\text { participants stressed the importance of getting a f } \\
\text { positively reflected in practices where lecturers } \\
\text { motivational teaching strategies in the classroom, dem } \\
\text { English lecturers' success stories, contextualizing, a } \\
\text { specific activities. Motivation is essential for learnin } \\
\text { differ depending on the situation. These results } \\
\text { Motivational Teaching Practices (MTP) paradigm nec } \\
\text { due to contextual factors. However, MTP componen } \\
\text { were ignored by lecturers. Realising MTP's import } \\
\text { learning outcomes in higher educational settings. }\end{array}$ & $\begin{array}{l}\text { nt's non-native English lecturers in } \\
\text { ase study examined how they think } \\
\text { t the knowledge into effect, and how } \\
\text { egies. This study focused on a single } \\
\text { lization were divided into two major } \\
\text { ers and thirteen English Literature } \\
\text { rticipants believed that there are two } \\
\text { motivation receiving more attention. } \\
\text { to participants in both clusters. Both } \\
\text { to obey. This understanding was } \\
\text { eloped, produced, and sustained } \\
\text { ating dominance. Sharing non-native } \\
\text { ccouraging were among the study's } \\
\text { it the type and techniques used can } \\
\text { cate that a proper and replicable } \\
\text { ated national or regional adaptations } \\
\text { evant to English Literature students } \\
\text { may lead to successfully achieving }\end{array}$ \\
\hline \multicolumn{2}{|c|}{ Keywords: Higher education classroom settings; motivational strategies; teachers' perceptions } \\
\hline $\begin{array}{cr}\text { First Received: } & \text { Revised } \\
\text { 19 March 2021 } & \text { 4 June 20 } \\
\text { Final Proof Received: } & \\
\text { 19 September 2021 } & \\
\end{array}$ & $\begin{array}{c}\text { Accepted: } \\
\text { 19 July 2021 } \\
\text { Published: } \\
\text { 30 September 2021 } \\
\end{array}$ \\
\hline $\begin{array}{l}\text { How to cite (in APA style): } \\
\text { Nur, S., Hardini, T. I., Patak, A. A. (2021). Non-nati } \\
\text { in a tertiary educational environment. Indonesi } \\
\quad 440-451 . \text { https://doi.org/10.17509/ijal.v11i2.32 }\end{array}$ & $\begin{array}{l}\text { sh lecturers' motivational practices } \\
\text { zal of Applied Linguistics, 11(2), }\end{array}$ \\
\hline
\end{tabular}

\section{INTRODUCTION}

One of the premises that defines the effectiveness of learning is the motivational teaching activities exhibited by teachers. This can considerably affect students' desire to learn and is considered the most critical factor affecting students' progress or failure in learning a language (Dörnyei, 2014). Even the brightest learners are unlikely to survive long enough to acquire any genuinely helpful language proficiency without adequate incentive, while most

\footnotetext{
*Corresponding Author

Email: sahrilfbsunm@unm.ac.id
}

motivated learners will achieve a working knowledge of the L2 regardless of the learning conditions (Moskovsky et al., 2013; Papi \& Abdollahzadeh, 2012)

Some previous studies have focused on intrinsic and extrinsic motivation (Kálmán \& Gutierrez Eugenio, 2015; Kreishan \& Al-Dhaimat, 2013; Ryan \& Deci, 2020; Vatankhah \& Tanbakooei, 2014). These studies were conducted overseas, which may or may not be applicable to 
Indonesia's EFL situation. Furthermore, these studies failed to distinguish between intrinsic and extrinsic motivation and integrative and instrumental motivation. Indeed, several studies have been performed in Indonesia (Astuti, 2015; Muslim et al., 2020; Yulia, 2013). These studies have been conducted mainly in the school context, resulting in minimal empirical evidence for EFL learners at the university level. As a result, it is essential to conduct a further study at the university level to explore various aspects of motivation, such as its complexity and significance at the higher education level.

This study fills a void in Indonesian university motivational practices by examining all motivational behaviors in the classroom. It is intended to be helpful to both English teachers and university students who can focus on their teaching practices. This study expands EFL teachers' understanding of the importance of student motivation and motivating teaching strategies in this foreign language learning context, especially in the context where students are aspiring to be future EFL teachers.

The current study aims to examine Indonesian EFL teachers' motivational techniques in their classroom teaching practices in a tertiary educational environment. This study focuses on how EFL teachers' instructional practices affect EFL students' learning motivation and commitment in a tertiary educational environment background in Indonesia. Overall, a deeper understanding of students' motivation and attitudes may help ESL/EFL curriculum and instruction designers create language teaching programs that foster the attitudes and motivation that lead to more effective ESL/EFL learners (Richards, 2013). It can also help content creators and teachers select activities and assignments that tap into students' inspiration and attitudes.

\section{Conceptualizing motivation}

Motivation is a factor that determines how often people want to do something (Reeve, 2014). In education, motivation is closely related to encouragement. Motivation is a very complex concept with many facets, and it is challenging to give a clear definition (Ushioda, 2012a). Behavioristic and constructivist researchers see motivation in various ways (Kaplan \& Patrick, 2016; Taber, 2015). Motivation is an abstract and theoretical construct that refers to the initiation, direction, intensity, consistency, and quality of behavior. According to $\mathrm{Li}$ and Keller (2018), motivation is described as people's decisions about the experiences or goals they will pursue or avoid, as well as the amount of effort they will put forth in doing so. This means that when a person considers doing something, motivation is a critical component.

Motivation encourages a person to put forth effort in order to accomplish a goal; it makes the individual persistent and attentive ( $\mathrm{Yu} \&$ Shen, 2012). Highly motivated individual loves pursuing a target and using tactics to achieve that goal. Motivation to learn a foreign language is often sparked when the learner perceives the language to be useful in comparison to the amount of work needed to master it. Motivation is described by Csizér (2017) as the dynamically changing cumulative arousal in an individual that initiates, directs, coordinates, amplifies, terminates, and evaluates the initial wishes' cognitive and motor processes and desires are selected, prioritized, operationalized, and carried out. In short, most researchers in the field of second/foreign language learning believe that motivation is closely linked to one's choice of action, commitment in following it, and effort put forward. In other words, motivation encompasses an inspiration that has the potential to serve as a powerful magnet, attracting an individual's attention and action.

\section{Motivational strategies in teaching English as a second/foreign language}

Motivation in education refers to the theoretical and practical considerations (Liu et al., 2016). Motivational techniques refer to those motivational forces that are deliberately exerted to achieve any systematic and lasting positive effects (Dörnyei \& Ushioda, 2013). Motivational techniques concerning classroom practices and environments as instructional measures implemented by the instructor to evoke and promote students' motivation (Sugita McEown \& Takeuchi, 2014). These motivational teaching methods are steps or approaches teachers use to help students become more involved in learning a second or foreign language. To this end, it is important to investigate what strategies non-native English lecturers use in the context of the research and how these techniques are used to improve student motivation.

Although researchers in the fields of education and educational psychology have suggested successful and motivating teaching methods, few have directly contributed to second/foreign language studies. Dörnyei et al. (2015) developed the most prominent system in the field of second/foreign language that can accommodate a variety of teaching strategies as a model for motivational second/foreign language teaching activity. Dornyei's comprehensive description of the extensive motivational methods in teaching a second/foreign language forms the basis of the framework.

Few studies have been performed to establish whether the suggested techniques are successful in language classrooms. The possibility that some teaching strategies' assumed and actual motivational power in second/foreign language learning can differ has troubled second/foreign language scholars (Dörnyei \& Ushioda, 2021). As a result, currently 
recommended teaching methods should be treated as mere theories to be evaluated to decide which strategies function best in a particular second/foreign language classroom. This research will also put Dornyei's structure to the test. We expect that not all the strategies outlined in the framework will be found in the current context; however, this analysis may uncover additional strategies not covered by the framework.

\section{METHOD}

\section{Research design}

This qualitative research used a case study approach to collect a wide variety of data and learn about the study participants' perspectives, attitudes, and biases. A case study is a good technique for answering "how" and "why" questions (Yin, 2017). The case study offers a detailed account and interpretation of one or more cases (Johnson \& Christensen, 2016). Since the research is performed within one case but includes more than one unit of analysis, this thesis uses the single embedded case study design (Yin, 2017). In other words, the investigation into motivational teaching strategies' attitudes and activities is performed in a single institution (a state university in Makassar). However, many non-native English lecturers and a group of student-teachers working and researching on the site are given special attention.

\section{Participants}

In this study, we purposefully invited participation from one cohort of students and the EFL teachers who taught a particular class in an English Education Department, Faculty of Languages and Literature, at a tertiary educational environment in one province of Sulawesi Island, Indonesia. Five third-year English Literature students and five nonnative English lecturers participated in this study. The English Literature has been abbreviated by Murphy and Rankin (2020) as the Elite. Reasons for selection include sufficient experience owned by Elite students upon learning English, and they will work or recently worked as teachers of English in several secondary schools. Another consideration is these mature students have adjusted to their study workload better that they would likely be more willing to participate in the study rather than the first-year students.

\section{Procedure}

Individual interviews with EFL teachers and student-teachers yielded the data. We used semistructured interviews to elicit the participants' beliefs, impressions, and insights on their learning and teaching experiences at this study site. We asked both EFL teachers and students some research-related variable questions through this instrument about their views of motivational methods used by EFL teachers in teaching at this specific teaching faculty. We conducted observation to validate the self-reported data and to triangulate data in addition to individual interviews with nonnative English lecturers and students. Observation is crucial because people do not always act the way they think they do (Johnson \& Christensen, 2016). We were able to record what teachers did in their classrooms to inspire students by using classroom observations. And we were able to check what was said and achieved using this tool.

We videotaped the instructor and observed what was going on during the observations. We used a coded observation focused on language learning's motivational dimension for classroom observations (Lamb, 2017). In the coding framework, we identified instances of the specified teaching strategies and making tallies for each strategy. During classroom observation, language learning motivation was used as a reference to record field notes of incidents of the teachers' motivational strategies.

\section{Data analysis and coding}

Nvivo8 was used to code and store all knowledge gathered from interviews and observations with lecturers and student-teachers for this report. Researchers may use the Nvivo8 program to restructure and use the data they have collected and systematize the study analysis process (Jackson \& Bazeley, 2019). The hierarchical node system in Nvivo8 enabled us to work with the transcripts systematically. The participants' opinions which are related to specific themes in the transcripts were coded following the interview, which was performed primarily in English. After the data had been coded, it was analyzed further by searching for themes. Dornyei's theoretical framework for motivational teaching methods for language learning was used in this research stage (Dörnyei et al., 2015). The coded transcripts to be used in the results chapter were proofed and edited for clarity after the data review was completed.

\section{FINDINGS}

\section{Lecturers' perceptions of motivation}

Non-native English lecturers in this study demonstrated a good understanding of strategies they could use to motivate students learning. They contend the significance of intrinsic and extrinsic motivations to execute a course of action to reach a goal. They realize that students' intrinsic motivation is more natural and is embedded in students' personalities.

The majority of students are well motivated because they have settled the expectation before taking their major. (Interview, non-native English lecturer 1) 
However, lecturers also signify the existence of determinant factors that could influence students' motivation. Such good understanding could assist lecturers to 'read' students various characteristics, particularly in terms of their motivation in learning.

We need to be aware that student motivation to learn is different from one another. This covers both family and educational background. Students' motivation is also affected by his or her individual differences such as age, personality and level of education. (Interview, non-native English lecturer 2)

This extract suggests that lecturers recognize their students' inner drive that is different for each student. Although this indicates a promising starting point that could lead to effective learning, the external factor is another crucial element to consider maximizing the function of internal motivation. We call this nurturing motivation; a motivation that needs to be continuously guided to maintain and develop its existence. This type of motivation characterizes direction, guidance, support, and control from lecturers.

Although lecturers perceived that most students had high intrinsic motivation, they were also sensitive to several hidden factors influencing students' decision to study the major subject. This includes parents' intimidation. (Interview, non-native English lecturer 1)

Students noted that students' different personalities and characters should lead lecturers to discover motivational strategies and approaches that could increase students' enthusiasm and engagement in learning.

It could also 'positively influence student perspective. (Interview, English Literature Student 1)

Agreeing upon students, lecturers reported the significance of their role in increasing student enthusiasm.

Motivation must be guided, not only from the inner part of the learner but also outside of the learner, the teacher. (Interview, non-native English lecturer 3)

These nurturing motivational model assumptions are comprehensively captured by students who seemed to be a hunger for the circumstance.

My motivation in learning English or another subject is highly affected by the teacher. If the teacher makes sure, the student can understand the materials perfectly and make sure that the student won't be bored in class, the motivation in learning also increases. (Interview, English Literature student 2)

Support from students signified that they expected their lecturers to explain the material comprehensively. This circumstance guided lecturers to creatively design learning scenarios and activities to stimulate and engage students learning. This covers several components such as teaching method, personality, physical appearance, and so on. Lecturers assumed that in addition to intrinsic motivation, lecturers should become the center of motive to lead the students found and empowered their functions, duties, and responsibilities.

Lecturers recommended several points, including 'teacher's way of teaching and their personality. (Interview, non-native English lecturer 2)

The nurturing model of motivational strategies discussed in this section essentially signifies the integration between intrinsic and extrinsic motivation where guidance and control from teachers or lecturers are hardly diminished. Although students argued that the utility of various motivational strategies could 'foster students' learning autonomy'.

Using many motivational strategies could foster our learning autonomy. (Interview, English Literature student 1)

Lecturers contended that their students' autonomous learning is not developed sufficiently. This forces lecturers to give protocol to most of the activities undertaken in the classroom. Lecturers illustrate their understanding of learning autonomy this way.

Teaching and learning activities should facilitate students to learn independently under teacher supervision. (Interview, non-native English lecturer 4)

\section{Lecturers' practices of motivational strategy}

Several themes embrace from lecturers' practices of motivational teaching strategies are being the role model, contextualizing, and giving reinforcement and feedback.

\section{The role models}

One crucial point lecturers insist on regarding lecturers' interpersonal skills is giving a good example to students. The interpersonal skills include a proving model for the English language and real life. The fore point relates to pedagogic and academic competence, and the latter is more to the personal and social quotient. Lecturers reported that by addressing these points, lecturers could present effective teaching.

As English teachers, we have to show our students that we can be good models of English speakers.... showing the students ability to speak English will motivate them to learn English more and more to be good English teachers in the future. (Interview, nonnative English lecturer 2)

This convincing statement appeared to influence students. They agree to this point and declare that they need a compelling figure that could inspire them to learn effectively. 
The lecturer needs to be a good model in using English because students will have a standard English model. (Interview, English Literature student 3)

In addition to being a good role model in academic performance, lecturers also attempted to develop students' positive character while teaching. non-native English lecturers realize that teaching is not only ensuring students' comprehension of the materials given; it also crucially relates to cultivating values for life. This is unique to the teaching world, one non-native English lecturer reflected.

The teacher's behavior should be a mirror for students to act and react toward things both inside and outside the classroom. They will always find the best model for guiding them to be knowledgeable and educated. (Interview, non-native English lecturer 4)

A similar idea highlights how lecturers developing students' positive character were conducted by reminding students about local wisdom shared in society. non-native English lecturers possibly perceived that reminding students about local values is part of strengthening their identity.

In Indonesia, we have philosophical value "Guru kencing berdiri, murid kencing berlari." This means that if the teacher or lecturer shows bad character (behavior), students tend to follow what the teachers do. The teacher as a role model in the classroom should illustrate good behavior in all respects. (nonnative English lecturer 5)

Students need for a complete figure to follow signified a solemn call. They were seriously hunger for inspiring prototypes, a model they could refer to both in academic and real life. This student signifies solid respect for a lecture

I keep motivated just by looking at how they teach and being a good role model at the same time. (Interview, English Literature student 2)

In short, in exploring the right figure to model, students understand that they need to improve their academic competence and maximize positive character growth. They were not only inspired by non-native English lecturers' deep knowledge, enthusiasm, and various experience. They also fell in love with their good attitude and behavior.

\section{Contextualizing}

All lecturers demonstrated an intention to relate their teaching materials to real-life situations and events. It appears from the observation that they interpret and demonstrate contextualizing in different ways. Some lecturers use the strategy to remind students about rules and values built among students and the wider community. One observation lecture reminds students about politeness and how students should interpret the tone used by lecturers when they arrive late to class. This lecturer explains how intonation, expressing language, and dictions could lead to different meanings. She further insists that words in communication are crucial as they could cause some misunderstanding. This is one of few lecturers who contextualize teaching by playing and switching diction and expression; she also relates her teaching materials with students' habits and social life context.

Another lecturer contextualizes her teaching by giving examples from both her own experience and others. This lecturer appears to be inspired by people around her and wishes her students could also get the same advantage. Once she argued.

I sometimes give stories of well-known persons who had been successful in their lives and highlighted how they became successful. I also tell my experiences which might motivate them. (Interview, non-native English lecturer 2)

Her practice supports this extract during a classroom observation. She discussed a good friend of hers who regularly writes an article in a local newspaper. She magnetized students and asked them to focus on this author's writing style. She asserted that the author had a clear writing structure that makes the message softly flow and easily understood by readers of all ages. This lecturer also told a success story to inspire students to study smarter. In her lecture, she mentioned some other experts and compared them with herself. She convinced students that she loves to ask herself to contest her contribution and what other people had given to society. Students reported that they could get advantages from inspiring stories and convincingly respond to this strategy as illustrated below:

By telling one awesome story to students, such as the one who is successfully gained her/his dream, automatically, the students will be motivated to follow the characters of the story. (Interview, English Literature student 4)

The contextualizing strategy appeared to be precious as connecting teaching materials with real experience could prevent us from boredom and lead us to stay motivated. This technique is also seen to be valuable because we were waiting for such inspiring success stories like going abroad and the struggle lecturers pass when they were learning to gain success, for instance, being lecturers. (Interview, English Literature student 5)

\section{Reinforcement and feedback}

Lecturers in the study demonstrated their willingness to motivate students to learn continuously. non-native English lecturers conducted several activities which aim to encourage students' positive retrospective self-evaluation. This includes giving assignments, summarizing lectures through reinforcement, and telling students' 
positions toward the material given. Lecturers reported this strategy effective.

Feedback about progress is helpful because learning is facilitated when the learner is aware that they are progressing towards the goals. (Interview, non-native English lecturer 2)

Lecturers appeared to actively assign students with tasks and activities to make them stay focus on the lesson. To understand and share students' position towards learning, lecturers stated that they were obliged to read, mark and appreciate students' submitted assignments. This is to help them give immediate feedback and inform lecturers about accurate decisions regarding strategies they should take for effective teaching. Lecturers appeared to use both written and verbal feedback. They signified the significance of these feedback types. One lecturer insisted on the efficacy of verbal feedback.

For the discussion, I directly gave [verbal feedback] for all groups who have done a task. After one presentation, I gave feedback; they have to respond to it and revise it based on my suggestion. (Interview, non-native English lecturer 3)

Supporting the strategy used by lecturers, students reported this strategy as one of the most preferred. They contended that their lecturers were consistent in giving them tasks and were 'never bored to remind them about it. However, one exciting strategy that students suggest being maintained in order that their motivation could stay high up to the end of the class period was rewarding. This strategy, unfortunately, is left reported by nonnative English lecturers in the study. It might be worth considering that giving rewards is a form of appreciating students' effort, they contended that at the end of lesson period, they usually lost focus, and that is why one student argued

Rewarding students for their achievement could enhance satisfaction after learning. (Interview, English Literature student 1)

\section{DISCUSSION}

\section{Perceptions of motivational teaching strategies}

Non-native English lecturers and English Literature students in the study agreed that motivation is categorized into natural and nurturing. Natural motivation is embedded in students' personality characteristics and is less significant compared to the other type. On the other hand, nurturing motivation is the external factor that non-native English lecturers and English Literature students perceive as more crucial and continuously developed. Natural and nurturing motivations are automatically connected, although they are derived from different sources. Nurturing motivation is more significant to stimulate students' learning compared to natural motivation. This means that motivation develops and is influenced by several factors. Participants of this study appeared to recall the distinction between intrinsic and extrinsic motivation, which was previously introduced by Ryan and Deci (2020). Although intrinsic motivation relates to long-term success in learning and could affect learners for a more extended period (Lasagabaster et al., 2014), this study's participants give a smaller proportion to this classification.

English Literature students in this study reported three types of natural motivation one of them is the preference in choosing a major subject. English Literature students argue that they have decided the major they wanted to study from the very beginning, and this choice becomes their primary goal that could bear comprehensive action. Similar findings by previous studies claim that personal challenge is one of the dominant language learning factors (Apple et al., 2013; Ushioda, 2011). These conditions confirm a claim states that intrinsically motivated people feel that they are doing an activity because it is challenging and could attest to their abilities and competencies (Jang, 2019; Ryan \& Deci, 2020). These findings agree with Dörnyei (2014), who states that the higher the power, the more creative an individual pursues an action that could lead them to use effective strategies.

The bigger component of the reported motivation from this study is nurturing motivation. It is the external drive that considerably influences one's motive and persistence to act. It represents Ryan and Deci (2020) extrinsic motivation. It is interesting to figure out that although extrinsic motivation is perceived to give short-term success in learning (Lasagabaster et al., 2014), it received higher agreement from participants in the study. Jang (2019) states that extrinsically motivated people are doing an activity because they wanted to obtain external rewards such as recognition, prizes, and good scores. This assumption possibly confirms that the study participants, particularly English Literature students, have positioned selfactualization as a determinant factor in maximizing their motivation. They need the lecturer's acknowledgment against their performance and perhaps to show off to other fellows.

Instead of acknowledging others, another crucial case from nurturing or extrinsic motivation from this study is the need for a figure to follow. This study reveals that the teacher factor is the most significant contribution to influence their motivation effectively. This finding echoed similar studies in the field Ghadirzadeh et al. (2012, Harumi (2011), Ushioda (2012b) who also recommend other factors such as classroom climate and assessment. However, the teacher factor agreement could be regarded as very strong as it is the only external aspect mentioned by participants. This might signify the teacher's influence in motivating English Literature students to learn a second/foreign language. This finding is unique because it 
replicates other studies conducted in high school settings (Astuti, 2015; Yeung et al., 2011). Hence, this study uncovers two exciting issues; the intention to be guided by lecturers signifies English Literature students' immature or strong dependency on others or the Indonesian context. The dependency might relate to cultural aspects that manipulate learners of all ages. This study also suggests that non-native English lecturers need to expend more effort and use more effective strategies to motivate students.

To sum up, integrating natural and nurturing motivation or intrinsic and extrinsic motivation is regarded as crucial as both are complementary. The circumstance that gives more priority to nurturing motivation denotes culture's influence in forming English Literature students' motivation. English Literature students appeared to continuously need someone to model, which could be a kind of 'whip' that functions as a motor to move students to reach their goals. Thus, it is clear that motivation consists of at least three elements. The decision to do a particular action, persistence in pursuing the actions, and the effort one expend to reach the goals (Masoomeh, 2016). The first two elements relate to natural motivation, and the last reflects nurturing motivation. Despite the distinct priority given to both types of motivation, they both play significant roles in motivating students to learn a second/foreign language.

\section{Practices of motivational teaching strategies}

This study is another confirmation of Dornyei's MTP framework. Findings from this study signify much simple motivational teaching practices compared to Dornyei's MTP. Adopting Dornyei's framework and accommodating the non-native English lecturers' strategies in teaching English as a foreign language in this study site, we presented the model with some new components derived from the findings of this study. This model is the complete figure from findings but only a tiny part of the elements presented in this article.

Figure 2

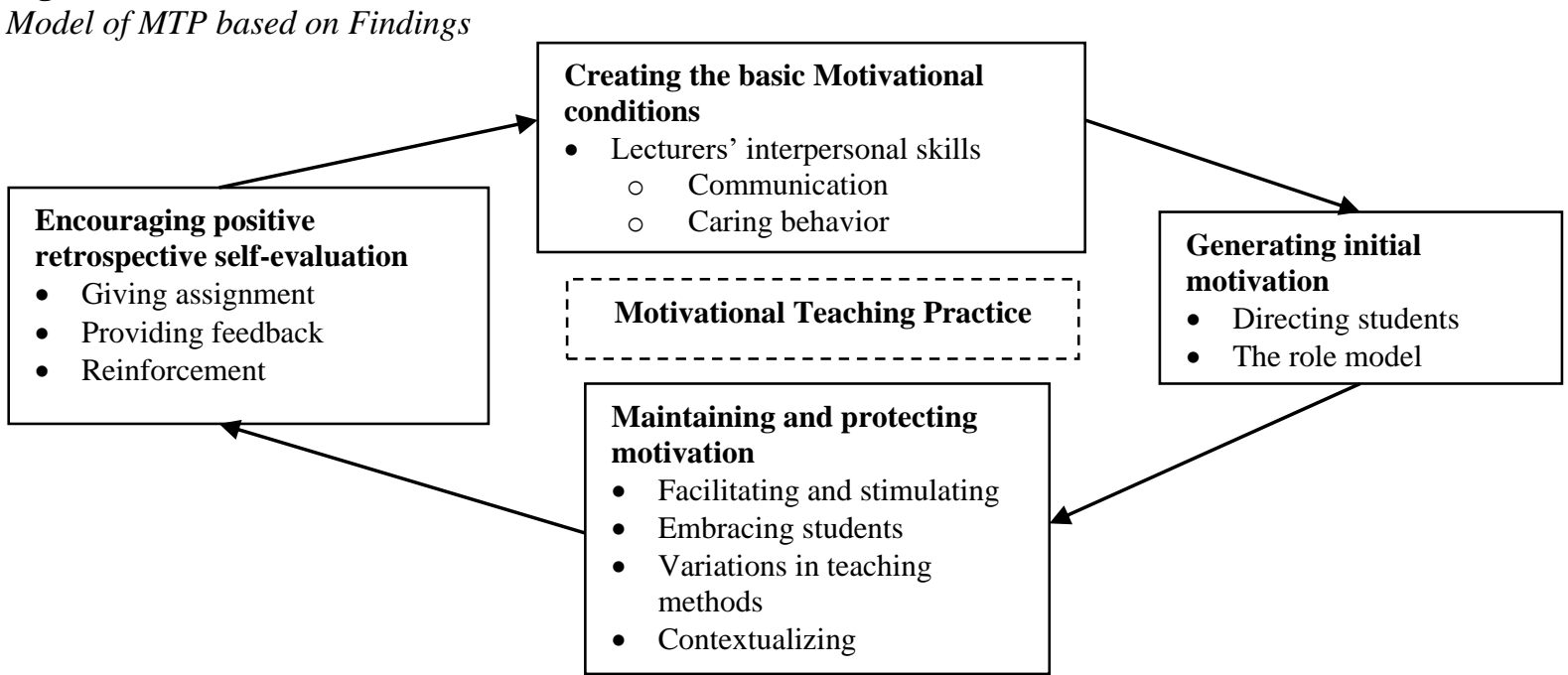

\section{Generating initial motivations}

Among five sub-strategies suggested in this phase, this study found that being the role model is crucial to signify the creation of realistic learner beliefs.

\section{The role models}

Participants in my study believed that lecturers should be role models for their students. In this study context, lecturers strongly influence their students. The attitudes and behaviors which teachers display in class are the patrons for students to follow. This means that teachers are the reference model for their students, which significantly impacts students' motivation to learn (Okoronkwo et al., 2013). However, EFL teachers need to make great efforts to create an excellent learning atmosphere in the classroom (Feng, 2014).

All the non-native English lecturers in this study were aware of their role as competent teachers. They attempted to be closely similar to a native speaker in producing some English utterances. Instead of modeling the right pronunciation to students, few EFL lectures undoubtedly guided students by showing the form or position of lips and tongue to say a word properly. In addition, although non-native English lecturers do not use full English in the instruction, the proportion outweighed the use of Bahasa Indonesia. Students warmly welcome the decision to use this instruction. They argue that the presentation of a good English model is more than just the performance of lecturers' competence; it inspires them to do their best to imitate and learn harder to meet the standards required by lecturers.

In addition to the role model academically, non-native English lecturers and students in this study also admitted to having real-life role models in terms of attitudes and behavior. They discussed 
enthusiasm, consistency, and high commitment to teaching. This kind of personality is regarded as meaningful to assist students learning and model a following worth figure. If the teacher presents a topic with enthusiasm, explains to his or her students that the topic is interesting, unique, essential, or worthwhile, students are likely to adopt the same attitude as the teacher (Brophy, 2013; Wentzel, 2020). Modeling is one way in which teachers can project enthusiasm for teaching. According to Dörnyei (2020), this process involves setting an example that involves motivational factors such as effort expenditure, positive attitudes, and interest in the subject.

Participants in this study also endorsed other issues relevant to a positive attitude that are worth following, such as fairness, politeness, and a smart dress code. non-native English lecturers and students perceived that these understandings are relevant to present and future life. non-native English lecturers argue that teachers should demonstrate a complete figure to stick to, and students are longing for inspiring figures that can develop their positive character to the maximum level. This strategy appears to relate to students' engagement in learning closely. Engaging students in both these two components signify a total commitment to teaching and learning.

This factor is similar to three dimensions of students' engagement covering behavioral, emotional, and cognitive (Fredricks \& McColskey, 2012). These scholars explained the significance of behavioral engagement as it could promote students' compliance with behavioral norms, such as attendance and involvement, and would demonstrate the absence of disruptive or negative behavior. They added that engaging students emotionally would lead them to experience affective reactions such as interest, enjoyment, and a sense of belonging. The last component, cognitive engagement for these scholars, is an investment in learning. Getting this asset would enable students to go beyond the requirements and would relish the challenge.

Although this explanation confirms the benefit of this strategy, it is also clear that the one found in this study is a model of students' absolute dependence on their lecturers. Students admitted to seriously need a role model that could engage them entirely in learning. non-native English lecturers also demonstrated their willingness to guide almost entirely as they understood their students' nature and behavior. This finding replicates other studies conducted in other Asian countries.

\section{Maintaining and protecting motivation}

This category of strategies concerns several elements, as shown in Figure 2. However, this study's findings showed only four motivational strategies related to this third stage of Dörnyei's framework for motivational teaching strategies. This study focuses on only one of these elements.

\section{Contextualizing}

Contextualizing or contextualization is defined as an instructional approach that focuses on integrating academic and occupational skills by connecting academic subjects to real-world situations (Ambrose et al., 2013). It refers to circumstances relevant to something under consideration, in this case, the everyday life and experiences students may have had or are likely to have. Thus, it is about connecting materials with something already known from ourselves or our own lives.

Findings from this study represent these definitions. Non-native English lecturers attempted to connect their teaching with their experience relevant to the materials being discussed. They shared stories of their own, stories of other inspiring figures, and related them to other social phenomena that occur in society and are familiar to students. This technique signifies non-native English lecturers' willingness to bring students closer to academic life and facilitate students' learning. The creation of such conditions enables students to make meaning of their lesson and life which is regarded effective strategy (Perin, 2011). Thus, it is consistent with the constructivist view of learning, where students attempt to make sense either from their own experience or other experience (nonnative English lecturers). In a constructivist approach, knowledge is constructed within a social context that includes symbols, tools, and language.

Language learning in the study context denotes the constructivist approach where non-native English lecturers favored contextualizing techniques in the classroom. Some examples of activities they have ranged from problem-solving, creativity, a small portion of critical thinking, and the integration of reading, writing, and presentation skills. In these activities, students can wed their teacher's past experiences and their own experiences. Contextualization, in this case, appeared to adopt the schema theory, which denotes that preexisting knowledge which agrees with relevant information promotes understanding and recall in language learning (Ferris \& Hedgcock, 2013).

To increase the potential of the contextualized lesson, teaching styles need to move away from the traditional teacher-centered approach. Several other techniques to support contextualization are using a feature of life, personalization by appealing to students' interest, using audio-visual materials, telling stories (both from lecturers and students), and address students' different learning styles (Korkmaz \& Korkmaz, 2013). Although non-native English lecturers do not use all these suggested techniques, they adapt most of them. The only category that is missed from the practice is personalization by addressing students' different 
learning styles. This component is a bit challenging because of the big class size and problems with approaching students. In responding to the latter issues, teachers usually do not touch the learning styles but more to hindrance factors that might disrupt students' learning.

This study uncovers new techniques for motivating students learning. Contextualization emerges as a strong theme that is supported by both non-native English lecturers and English Literature students in the study. Sharing success stories is perceived to effectively encourage, inspire, and empower students to either shape a positive impression against the lesson or encourage them to participate during class activities.

\section{Encouraging positive retrospective self- evaluation}

Dörnyei's framework's final step involves encouraging motivational attributions, providing motivational input, learner satisfaction, and offering rewards and grades in a motivating manner (Dörnyei et al., 2015). Motivational attribution is teaching the learner to appraise and respond favorably to their previous learning. The first part is only addressed in this report, with two sub-sections addressing feedback and reinforcement. A teacher will encourage students to think positively about their learning achievements by assisting them in becoming more pleased with their achievement and development, offering positive feedback that encourages continued learning, and awarding incentives and grades in class (Dörnyei, 2020).

\section{Giving feedback}

This study's findings revealed that lecturers did not inspire their students to justify their past successes and failures in positive ways, nor did they help them become more pleased with their achievements and development. Few lecturers in this study mentioned checking students' work, either by reminding them of their assignments or by looking at the completed assignments, correcting, and asking students to make revisions directly. Students said that this form of feedback is motivating because the mission is far more transparent. Teachers who tell students they are doing well or provide corrective material, according to Schunk et al., (2014), help substantiate students' self-efficacy for learning. This exposes a form of instruction provided by lecturers to assist students in achieving a specific goal.

One point of contention between students and lecturers was the use of suggestions, according to this report. None of the non-native English lecturers mentioned giving students awards, and the practice was also absent during observation, but students strongly expressed their dissatisfaction. There is no further information about the lecturers' decision on this point, but other studies have shown that this type of feedback can demotivate students. When teachers are concerned about a student's insufficient progress due to their low ability to learn, it can deplete students' motivation (Morgan \& Neil, 2014). Teachers encouraging students, on the other hand, are not often used as a motivating tool. According to Brophy (2013) and Wentzel (2020), students may find it humiliating to be singled out, humiliating to be praised for minor achievements, or annoying to have classmates' attention drawn to their neatness, punctuality, or conformity behaviors rather than to more explicitly noteworthy achievements. Brophy says that effective recognition should be focused on the learners' efforts or respect for their successes, not on their role in satisfying the instructor. This type of incentive may be thought of as a small celebration of what students have learned or achieved. According to another author, many students prefer private praise to public praise. These recommendations show that praising can have both positive and negative consequences.

None of the five teachers in this study listed assisting their students in self-evaluation. They also failed to note how they helped their students determine the most effective method of learning English. Maybe this is due to the essence of the Indonesian school curriculum, teaching methods, and evaluation (Astuti, 2015). Furthermore, the motivational techniques used in a language classroom may not meet all of the students' needs.

\section{Giving reinforcement}

Giving affirmation is a new aspect of motivational techniques that emerged from this research. Before beginning presenting a new subject or closing the lesson, non-native English lecturers in this study liked to remind students about the previously discussed content. Students considered this approach to be both positively empowering and successful in retaining their interest in learning. This strategy is unique in that it is neither stated in Dornyei's MTP system nor suggested in other Indonesian studies (Astuti, 2015, 2016; Kassing, 2011).

\section{CONCLUSION}

This research replicates Dornyei's MTP techniques, but it does not follow all of them to the letter. Several elements can be transferred from one step to the next, but a few are unique to this analysis. Reasonable instructor habits, a friendly and welcoming classroom environment, increasing the learners' target orientedness and making the teaching materials important for the learners are among those that are transferrable. Furthermore, non-native English lecturers in the study presented tasks in a motivating manner, stimulating learning, encouraging collaboration among students, and providing motivational feedback. This is 
comparable to Astuti (2015), Astuti (2016), and Kassing (2011) findings. The new components proposed in this study are from Dornyeis' MTP framework's third and fourth phases. They connect teaching materials to students' real-world experiences and provide feedback to students to enhance the meaning-making process's consistency. These elements should be used to complement the framework's overall statistic, or they should be challenged further in a future report.

This study shed light on the perceptions and practices of MTP among non-native English lecturers. This research contributes significantly to a paradigm for understanding perceptions of motivational strategies that are effective in the study setting. This structure may be specific to the study setting, but other sites with similar schooling, context, and cultural elements may likely yield similar results. More specifically, rather than adopting a single international model, the conceptual framework allows researchers to continue looking for an appropriate model that fits a specific context. More lecturers studying the new components could provide more detail. Focus groups may also be used to validate and endorse participants' self-reported data. Finally, this research introduces new MTP system elements. Researchers may extend the MTP model to suit their context better with a further study using the new conceptual framework's suggested components.

\section{REFERENCES}

Ambrose, V. K., Davis, C. A., \& Ziegler, M. F. (2013). From research to practice: A framework for contextualizing teaching and learning. Journal of College Reading and Learning, 44(1), 35-50. https://doi.org/10.1080/10790195.2013.10850 371

Apple, M. T., Da Silva, D., \& Fellner, T. (2013). Language learning motivation in Japan. Multilingual Matters.

Astuti, S. P. (2015). Teachers' and students' perceptions of motivational teaching strategies in an Indonesian high school context. TEFLIN Journal, 24(1), 1-18. http://dx.doi.org/10.15639/teflinjournal.v24i1/ 14-31

Astuti, S. P. (2016). Exploring motivational strategies of successful teachers. TEFLIN Journal, 27(1), 1-22. https://doi.org/10.15639/teflinjournal.v27i1/122

Brophy, J. E. (2013). Motivating students to learn. Taylor \& Francis.

Csizér, K. (2017). Motivation in the L2 classroom. In S. Loewen \& M. Sato (Eds.), The Routledge handbook of instructed second language acquisition (pp. 418-432).
Routledge.

Dörnyei, Z. (2014). The psychology of the language learner: Individual differences in second language acquisition. Taylor \& Francis.

Dörnyei, Z. (2020). Innovations and challenges in language learning motivation. Routledge.

Dörnyei, Z., Henry, A., \& Muir, C. (2015). Motivational currents in language learning: Frameworks for focused interventions. Taylor $\&$ Francis.

Dörnyei, Z., \& Ushioda, E. (2013). Teaching and researching motivation. Taylor \& Francis.

Dörnyei, Z., \& Ushioda, E. (2021). Teaching and researching motivation. Taylor \& Francis.

Feng, Z. (2014). Using teacher questions to enhance EFL students' critical thinking ability. Journal of Curriculum and Teaching, 2(2), 147-153. https://doi.org/10.5430/jct.v2n2p147

Ferris, D. R., \& Hedgcock, J. (2013). Teaching L2 composition: Purpose, process, and practice. Routledge.

Fredricks, J. A., \& McColskey, W. (2012). The measurement of student engagement: A comparative analysis of various methods and student self-report instruments. In S. L. Christenson, A. L. Reschly, \& C. Wylie (Eds.), Handbook of Research on Student Engagement (pp. 763-782). Springer. https://doi.org/10.1007/978-1-4614-20187_37

Ghadirzadeh, R., Hashtroudi, F. P., \& Shokri, O. (2012). Demotivating factors for English language learning among university students. Journal of Social Sciences, 8(2), 189-195. https://doi.org/10.3844/jssp.2012.189.195

Harumi, S. (2011). Classroom silence: Voices from Japanese EFL learners. ELT Journal, 65(3), 260-269. https://doi.org/10.1093/elt/ccq046

Jackson, K., \& Bazeley, P. (2019). Qualitative data analysis with NVivo. Sage.

Jang, H.-R. (2019). Teachers' intrinsic vs. extrinsic instructional goals predict their classroom motivating styles. Learning and Instruction, 60, 286-300.

http://doi.org/10.1016/j.learninstruc.2017.11.0 01

Johnson, R. B., \& Christensen, L. (2016). Educational research: Quantitative, qualitative, and mixed approaches. SAGE Publications.

Kálmán, C., \& Gutierrez Eugenio, E. (2015). Successful language learning in a corporate setting: The role of attribution theory and its relation to intrinsic and extrinsic motivation. Studies in Second Language Learning and Teaching, 5(4), 583-608. https://doi.org/10.14746/ssllt.2015.5.4.4

Kaplan, A., \& Patrick, H. (2016). Learning environments and motivation. In K. R. Wentzel \& D. B. Miele (Eds.), Handbook of 
motivation at school (pp. 254-274).

Routledge.

Kassing, R. B. (2011). Perceptions of motivational teaching strategies in an EFL classroom: The case of a class in a private university in Indonesia. CORE, 41337143. https://core.ac.uk/download/pdf/41337143.pdf

Korkmaz, S., \& Korkmaz, Ş. Ç. (2013).

Contextualization or de-contextualization: Student teachers' perceptions about teaching a language in context. Procedia-Social and Behavioral Sciences, 93, 895-899. https://doi.org/10.1016/J.SBSPRO.2013.09.29 9

Kreishan, L. J., \& Al-Dhaimat, Y. (2013). Intrinsic and extrinsic motivation, orientation and achievements in L2 of Arab learners of English, French and German: A study from Jordan. International Education Studies, 6(12), 52-63. https://doi.org/10.5539/ies.v6n12p52

Lamb, M. (2017). The motivational dimension of language teaching. Language Teaching, 50(3), 301-346. https://doi.org/10.1017/S0261444817000088

Lasagabaster, D., Doiz, A., \& Sierra, J. M. (2014). Motivation and foreign language learning: From theory to practice (Vol. 40). John Benjamins Publishing Company.

Li, K., \& Keller, J. M. (2018). Use of the ARCS model in education: A literature review. Computers \& Education, 122, 54-62. https://doi.org/10.1016/j.compedu.2018.03.01 9

Liu, W. C., Wang, J. C. K., \& Ryan, R. M. (Eds.) (2016). Understanding motivation in education: theoretical and practical considerations. In Building autonomous learners (pp. 1-7). Springer.

Masoomeh, K. (2016). Self-efficacy and strategy use in the multi-variate model of motivation for English language learners in Iran/Masoomeh Khodadad (Unpublished doctoral thesis). University of Malaya.

Morgan, C., \& Neil, P. (2014). Teaching modern foreign languages: A handbook for teachers. Taylor \& Francis.

Moskovsky, C., Alrabai, F., Paolini, S., \& Ratcheva, S. (2013). The effects of teachers' motivational strategies on learners' motivation: A controlled investigation of second language acquisition. Language

Learning, 63(1), 34-62. http://dx.doi.org/10.1111/j.14679922.2012.00717.x

Murphy, B. L., \& Rankin, E. M. (2020). 5 Steps to a 5: AP English literature 2021 Elite (student edition). McGraw-Hill Education.

Muslim, A. B., Hamied, F. A., \& Sukyadi, D. (2020). Integrative and instrumental but low investment: The English learning motivation of Indonesian senior high school students. Indonesian Journal of Applied Linguistics, 9(3), 493-507. https://doi.org/10.17509/ijal.v9i3.23199

Okoronkwo, I. L., Onyia-Pat, J.-L., Agbo, M.-A. E., Okpala, P. U., \& Ndu, A. C. (2013). Students' perception of effective clinical teaching and teacher behaviour. Open Journal of Nursing, 3(1), 63-70. https://dx.doi.org/ 10.4236/ojn.2013.31008

Papi, M., \& Abdollahzadeh, E. (2012). Teacher motivational practice, student motivation, and possible L2 selves: An examination in the Iranian EFL context. Language Learning, 62(2), 571-594.

https://doi.org/10.1111/j.14679922.2011.00632.x

Perin, D. (2011). Facilitating student learning through contextualization. Community College Review, 39(3), 268-295. https://doi.org/10.1177/0091552111416227

Reeve, J. (2014). Understanding motivation and emotion. John Wiley \& Sons.

Richards, J. C. (2013). Curriculum approaches in language teaching: Forward, central, and backward design. RELC Journal, 44(1), 5-33. https://doi.org/10.1177/0033688212473293

Ryan, R. M., \& Deci, E. L. (2020). Intrinsic and extrinsic motivation from a self-determination theory perspective: Definitions, theory, practices, and future directions. Contemporary Educational Psychology, 61, 101860. https://doi.org/10.1016/j.cedpsych.2020.10186 0

Schunk, D. H., Meece, J. L., \& Pintrich, P. R. (2014). Motivation in education: Theory, research, and applications. Pearson.

Sugita McEown, M., \& Takeuchi, O. (2014). Motivational strategies in EFL classrooms: How do teachers impact students' motivation? Innovation in Language Learning and Teaching, 8(1), 20-38. https://doi.org/10.1080/17501229.2012.74113 3

Taber, K. S. (2015). Meeting educational objectives in the affective and cognitive domains: Personal and social constructivist perspectives on enjoyment, motivation and learning chemistry. In M. Kahveci \& M. Orgill (Eds.), Affective dimensions in chemistry education (pp. 3-27). Springer.

Ushioda, E. (2011). Language learning motivation, self and identity: Current theoretical perspectives. Computer Assisted Language Learning, 24(3), 199-210. https://doi.org/10.1080/09588221.2010.53870 1

Ushioda, E. (2012a). Motivation in second language acquisition. In C. A. Chapelle (Ed.), The 
encyclopedia of applied linguistics.

Routledge.

Ushioda, E. (2012b). Motivation and L2 learning: Towards a holistic analysis. In Views on Motivation and Autonomy in ELT: Selected Papers from the XXXVII FAAPI Conference (pp. 14-19).

http://infohumanidades.com/sites/default/files/ apuntes/Ushioda.2012.\%20Motivation\%20and \%20L2\%20learning.pdf

Vatankhah, M., \& Tanbakooei, N. (2014). The role of social support on intrinsic and extrinsic motivation among Iranian EFL learners. Procedia-Social and Behavioral Sciences, 98, 1912-1918. https://doi.org/10.1016/j.sbspro.2014.03.622

Wentzel, K. (2020). Motivating students to learn. Taylor \& Francis.

Yeung, A. S., Lau, S., \& Nie, Y. (2011). Primary and secondary students' motivation in learning English: Grade and gender differences. Contemporary Educational Psychology, 36(3), 246-256. https://doi.org/10.1016/j.cedpsych.2011.03.00 1

Yin, R. K. (2017). Case study research and applications: Design and methods. SAGE Publications.

Yu, B., \& Shen, H. (2012). Predicting roles of linguistic confidence, integrative motivation and second language proficiency on crosscultural adaptation. International Journal of Intercultural Relations, 36(1), 72-82. https://doi.org/10.1016/j.ijintrel.2010.12.002

Yulia, Y. (2013). Teaching challenges in Indonesia: Motivating students and teachers' classroom language. Indonesian Journal of Applied Linguistics, 3(1), 1-16. https://doi.org/10.17509/ijal.v3i1.186 